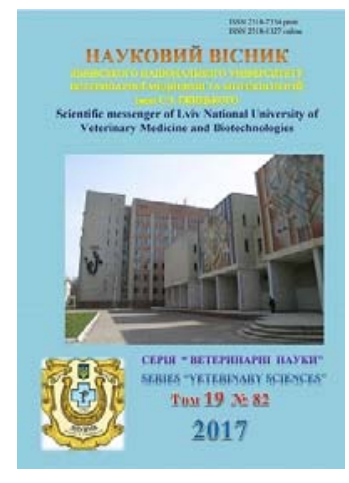

Науковий вісник Львівського національного університету ветеринарної медицини та біотехнологій імені С.З. Гжицького

Scientific Messenger of Lviv National University of Veterinary Medicine and Biotechnologies

doi:10.15421/nvlvet8224

ISSN 2518-7554 print

ISSN 2518-1327 online

http://nvlvet.com.ua/

УДК 619. 477

\title{
Початки лікувальної справи тварин у Львові
}

\author{
В.Я. Присяжнюк \\ Vasyl.prysyaznyuk@gmail.com
}

Львівський національний університет ветеринарної медицини та біотехнологій імені С.3. Гжицького, вул Пекарська, 50, м. Львів, 79010, Украӥна

Уже в $13 \mathrm{~cm}$. Львів був не лише політичним, стратегічним, а й економічним центром з розвиненими ремеслом і торгівлею. Відомо, що середньовічне місто не могло існувати без наявності в ньому ремісників таких основних професій, як кравиів, шевиів, пекарів, ковалів, різників та гончарів. У найстарішій міській книзі, яка дійшла до нас, написаній після пожежі 1381 р., згадується чимало професій і прізвищ львівських ремісників, серед них 8 різників, 2 ковалі. За неповними даними, в 1405-1426 рр. у Львові були ремісники 36 професій, в тому числі 14 різників, 11 ковалів. Протягом XV - першої половини ХVII століття Львів був ремісничим, освітнім та культурним центром України завдяки тому, щяо стояв на перетині великих європейських иляхів та був відомим ринковим центром збуту, обміну та товарного виробництва у Центральній та Південній Європі. Підтвердженням цього є відкриття у 1439 рочі релігійно-просвітницького товариства «Львівське братство». Першими школами з підготовки фахівців лікувальної справи були родинні, тобто сімейні школи. Пізніше школи стали називатися цехами. У $14 \mathrm{~cm}$. иехи були самостійними вищими навчальними закладами і не входили до складу університетів навіть у Європі, оскільки це регламентувалося статутами університетів. Цехи України пізніше започаткували академії та університети і мали атрибутику вищих навчальних закладів: статут, прапор, печатку, иіхи, ікони, щңо засвідчували місце і значення школи (цеху) у житті краӥни. Грамоту на відкриття школи давав князь (король). Статут цеху поширювався на членів об'єднання: учень, підмайстер і майстер. Цехові статути були документами правового значення $i$ часто майже не змінювалися упродовж століть. Середньовічні архівні документи XIV - першої половини XVII століття (цехові статути, книги запису поточних справ, актові книги міської влади) досить повно відображають цехову структуру Львова не тільки кількісно, а й фахово. У Львівському державному історичному архіві зберігаються два найдавніші статути ковальського цеху 1529 і 1558 рр. У Львові в ХІV столітті було чотири, а в 1425 роиі вже діяло 10 иехів: ковалів, сідлярів, різників, шевців, крамарів, пекарів, кушнірів, лимарів, гарбарів та пивоварів, в 1462-1483 р.р. ремісники понад 50 професій були об'єднані в 14 иехів. У 1579 роиі було вже 20 цехів, а в першій половині ХVІІ століття кількість иехів у Львові досягла 30, в які об'єднались понад 500 майстрів 133 спеціальностей. Підготовка спеціалістів лікувальної справи тварин в Україні, та відповідно у Львові довгий час велася при иехах ковалів. У подальшому ковалі-коновали займалися лікуванням не тільки коней, а й інших тварин. Особливо в боротьбі з пошесними захворюваннями тварин вони збагачували досвід лікувальної практики, який передавали наступним поколінням.

Проте все че були навчальні заклади, в яких готували невелику кількість фахівців лікувальної справи, а більшу частину населення і тварин обслуговували знахарі, кровопускачі, ковалі, коновали. Зародження і розвиток иехової структури було наслідком піднесення економічно-торгівельних та культурно-освітніх зв'язків у середньовічному Львові, щзо дало початок лікувальній справі тварин, а в подальшому - відкриттю шкіл $і$ зародженню ветеринарної освіти в Галичині.

Ключові слова: Львів, цехи, статути, ковалі, різники, иколи, навчання, майстри, лікувальна справа, тварини.

\section{Начало лечебного дела животных во Львове}

\author{
В.Я. Присяжнюк \\ Vasyl. prysyaznyuk@ gmail com
}

Львовский национальный университет ветеринарной медицины и биотехнологий имени С.3.Гжицкого, ул. Пекарская, 50, г. Львов, 79010, Украина

Citation:

Prusyazhnyuk, V. (2017). The beginnings of the treatment of animals in Lviv. Scientific Messenger LNUVMB, 19(82), $114-119$. 
Уже в 13 столетии Львов был не только политическим, стратегическим, но и экономическим центром с развитьм ремеслом и торговлей. Известно, что средневековый город не мог существовать без наличия в нем ремесленников таких основных профессий, как портных, сапожников, пекарей, кузнецов, резников, гончаров. В старейшей городской книге, которая сохранилась до наших дней, написанной после пожара 1381 года, вспоминается достаточно профессий и фамилий львовских ремесленников, среди них 8 резников и 2 кузнеца. За неполныли данными в $1405-1426$ г.2. во Львове были ремесленники 36 профессий, в том числе 14 резников и 11 кузнецов. На протяжении 15 - первой половины 17 столетия Львов был ремесленным, образовательным и культурным центром Украины вследствии того, что стоял на пересечении больиих европейских дорог и был известным рыночным центром сбыта, обмена и товарного производства в иентральной и южной Европе. Подтверждением этого есть открытие в 1439 году религиозно - просветительского общества « Львовское братство». Первыми школами по подготовке специалистов лечебного дела были семейные иколь. Позже они стали называться иехами. В 14 столетии ичеха были самостоятельными и не входили в состав университетов даже в Европе, поскольку это регламентировалось уставами университетов. Цеха Украинь позднее дали начало высшим учебным заведениям и имели атрибутику университетов: устав, знамя, печать, ичихи, иконь, что свидетельствовало о месте и значении икольл в жизни страны. Грамоту на открытие иколь давал князь (король). Устав иеха распространялся на членов объединения: ученик, подмастер, мастер. Цеховые уставы были документами правового значения и часто почти не изменялись на протяжении столетий. Средневековые архивные документы 15 - первой половины 17 столетия (цеховые уставы, книги записей текущих дел, актовые книги городской власти) достаточно полно отражают иеховую структуру Львова не только количественно, но и качественно. В Львовском государственном историческом архиве хранятся два наиболее древних устава иеха кузнецов 1529 и 1558 га. Во Львове в 14 столетии было 4, а в 1425 году уже действовало 10 иехов, в $1462-1483$ г2. ремесленники свыше 50 профессий были объединены в 14 цехов. В 1579 году было уже 20 цехов, а в первой половине 17 ст. количество цехов во Львове достигло 30, в которые объединились свыше 500 мастеров 133 специальностей. Подготовка специалистов лечебного дела животных в Украине и соответственно во Львове долгое время осуществлялась при ичехах кузнецов. В дальнейшем кузнецы - коноваль занимались лечением не только лошадей но и других животных. Особенно в борьбе с заразными заболеваниями животных они обогащзали опыт лечебной практики, который передавали следующим поколениям. Но это были учебные заведения, в которых готовили небольшое количество специилистов лечебного дела, а большую часть населения и животных обслуживали знахари, кровопуски, кузнецы, коноваль.

Зарождение и развитие иеховой структуры было следствием подъема экономическо-торговых и культурнообразовательных связей в средневековом Львове, которое дало начало лечебному делу животных, а в дальнейшем открытию икол и развитию ветеринарного образования в Галичине.

Ключевые слова: Львов, цуеха, уставы, кузнецьы, резники, иколь, обучение, мастера, лечебное дело, животные.

\title{
The beginnings of the treatment of animals in Lviv
}

\author{
V. Prusyazhnyuk \\ Vasyl.prysyaznyuk@gmail com
}

\author{
Stepan Gzhytskyi National University of Veterinary Medicine and Biotechnologies Lviv, \\ Pekarska Str., 50, Lviv, 79010, Ukraine
}

Already in the 13th century. Lviv was not only a political, strategic, but also an economic center with developed craft and trade. It is known that a medieval city could not exist without the presence of craftsmen of such basic professions as tailors, shoemakers, bakeries, blacksmiths, cutters and potters. In the oldest city book that came to us, written after the fire of 1381, it is mentioned a lot of occupations and names of Lviv artisans, among them 8 cutters, 2 blacksmiths. According to incomplete data from 1405-1426, in Lviv there were artisans of 36 occupations, including 14 cutters, 11 blacksmiths. During the XV-first half of the XVII century, Lviv was the artisan, educational and cultural center of Ukraine due to the fact that it stood at the intersection of major European roads and was a well-known market center for sales, exchange and commodity production in Central and Southern Europe. Confirmation of this is the discovery in 1439 of the religious-educational society "Lviv Brotherhood». The first schools for the training of medical specialists were family, that is, family schools. Later, the schools became known as workshops. In the 14th century the workshops were independent higher educational institutions and were not part of the universities, even in Europe, as it was regulated by the statutes of universities. Ukrainian workshops later started out academies and universities and had the attributes of higher educational institutions: statute, flag, seal, ciches, icons, which testified the place and importance of the school (shop) in the life of the country. The prince (king) gave the certificate of the opening of the school. The statute of the work shop was extended to members of the association: a student, an apprentice and a master. Workshops statutes were legal documents and often were not changed much for centuries. Medieval archival documents of the XIV-first half of the XVII century (workshops statutes, books on current affairs, books of the city authorities) quite fully reflect the Lviv workshop structure not only quantitatively but also professionally. The two oldest statutes of the blacksmith shop in 1529 and 1558 are stored in the Lviv State Historical Archives. In Lviv in the fourteenth century there were four, and in the year 1425 there were already 10 work shops: blacksmiths, saddles, cutters, shoemakers, shopkeepers, bakeries, furriers, limars, gardens and brewers. In 1579 there were already 20 work shops, and in the first half of the XVII century the number of work shops in Lviv reached 30, which united over 500 masters of 133 specialties. In the future, the blacksmiths-conquerors were engaged in the treatment of not only horses but other animals. Particularly in the fight against poisonous animal diseases, they enriched the experience of medical practice, which was passed on to subsequent generations. However, all of these were educational institutions, in which a small number of qualified medical specialists trained, and the majority of the population and animals were served by healers, bloodshed, blacksmiths, and veterinary doctors. Opening in 1457 in the blacksmith work shop of veterinary school and horses forging was the result of the rise of trade and economic, cultural and educational ties in the medieval city, which was contributed to the birth and development of the work shop structure that gave the beginning of a medical case, and later - the birth of veterinary education in Galicia.

Key words: Lviv, workshops, statutes, blacksmiths, cutters, schools, training, masters, medical treatment, animals. 


\section{Вступ}

Актуальність теми. Впродовж останніх років опубліковано цілу низку наукових досліджень вітчизняних авторів $(3,4,6)$, присвячених історії медицини, що розкривають питання зародження, становлення та розвитку лікувальної справи, в тому числі у різних регіонах України залежно від політичних і соціальноекономічних умов. У значній кількості наукових праць показано організацію і становлення державної ветеринарної служби певного краю, області (Verkhratskyi and Zabludovskyi, 1991; Aranchii, 1998; Rudyk and Bisiuk, 2000; Kurtiak and Tkachuk, 2001; Sytarchuk, 2002) і України в цілому (Verbytskyi et al., 2002).

Мета дослідження: висвітлити питання підготовки фахівців лікувальної справи з метою недопущення захворювань та лікування тварин в певних історичних умовах в Галичині. Завдання дослідження полягали в тому, щоб отримати дані щодо організації форм підготовки фахівців лікувальної справи тварин в давні часи у Львові, розкрити сутність цехової системи навчання у певних політичних та соціальноекономічних умовах Львова, висвітлити діяльність цехів ковалів, різників з метою зменшення захворюваності тварин і людей, кількісний і якісний склад цехів у 15-17 століттях у Львові.

\section{Матеріал і методи досліджень}

Матеріалом для вивчення лікувальної справи тварин на західноукраїнських землях були окремі архівні документи центрального державного історичного архіву м. Львова, періодичні видання, статті, а також деякі вітчизняні та іноземні бібліографічні джерела Національної наукової бібліотеки імені В. Стефаника НАН України у м. Львові. При проведенні досліджень використано методи: хронологічний, системний, порівняльно-історичний, аналітичний.

\section{Результати та їх обговорення}

Коріння ветеринарної освіти необхідно шукати у далекій давнині. Першими школами 3 підготовки фахівців лікувальної справи були родинні, тобто сімейні школи. Пізніше школи стали називатися цехами. У 14 ст. цехи були самостійними вищими навчальними закладами і не входили до складу університетів навіть у Свропі, оскільки це регламентувалося статутами університетів.

Цехи України пізніше започаткували академії та університети і мали атрибутику вищих навчальних закладів: статут, прапор, печатку, ціхи, ікони, що засвідчували місце і значення школи (цеху) у житті країни. Грамоту на відкриття школи давав князь (король). Статут цеху поширювався на членів об'єднання: учень, підмайстер і майстер. Цехові статути були документами правового значення і часто майже не змінювалися упродовж століть.

Уже в 13 ст. Львів був не лише політичним, стратегічним а й економічним центром з розвиненим ремеслом і торгівлею. Відомо, що середньовічне місто не могло існувати без наявності в ньому ремісників таких основних професій, як кравців, шевців, пекарів, ковалів, різників та гончарів. У найстарішій міській книзі, яка дійшла до нас, написаній після пожежі 1381 р., згадується чимало професій і прізвищ львівських ремісників, серед них чинбар, 8 різників, 2 ковалі. За неповними даними, в 1405-1426 рр. у Львові були ремісники 36 професій, в тому числі 14 різників, 11 ковалів, 8 чинбарів (Vytiahy z Lvivskykh zemskykh i miskykh aktiv u spravakh mista za 1411-1786 rr).

Про існування 10 львівських ремісничих цехів свідчить документ 1425 р., у якому згадуються цехи різників, ковалів, чинбарів, кушнірів, шевців, кравців, римарів, сідлярів, пивоварів (Kis, 1968). У 1447 р. за львівськими цехами було закріплено для оборони окремі міські башти і ділянки стін. Різники, ковалі разом з голкарями і слюсарями стояли біля Галицької брами.

У 1462-1483 рр. ремісники понад 50 професій були об'єднані в 14 цехів (братств), однак у той час ще зустрічаємо багато випадків, коли до окремих цехів належать ремісники споріднених професій. Наприклад, до цеху ковалів і слюсарів належали ремісники, котрі виготовляли вироби із заліза - ковалі, слюсарі, мечники, ливарники, голкарі, а також поясники.

У 15 - на початку 16 ст. у Львові найкраще розвивалися кравецьке, шевське, кушнірське, ковальське, слюсарське, різницьке, пивоварне і медоварне ремесла, що було пов'язано з економічним розвитком міста i краю, розширенням внутрішнього та зовнішнього ринку, посиленням попиту на товари.

Статути цехів складалися здебільшого самими цехами, міською радою, а іноді запозичувалися зі статутів інших міст. Статути цехів затверджувалися міською радою або королями. На навчання до цехів брали учнів віком від 14 до 24 років, що засвідчують записи у цехових книгах. Щоб вступити на навчання, кожен учень повинен був подати документ про народження, а інколи - ще додатково рекомендацію шляхтича чи знатного міщанина. Цехові статути регламентували також кількість учнів, яких міг прийняти на навчання майстер.

Тривалість навчання теж визначалася цеховими статутами залежно від складності професії та традиціі. Якщо тривалість навчання учня не регламентувалася цеховими статутами, то його визначали самі цехи. Навчання тривало від 3 до 7 років. Після оволодіння вибраною професією наставав день переведення учня в підмайстри, або, як тоді говорили, «визволення» (Knyha zapysiv protokoliv vyzvolennia tsekhu kovaliv). Ця подія супроводжувалася відповідними церемоніями і відбувалася на зборах цеху. Підмайстри окремих цехів мали своє приміщення, куди сходилися на збори чи розваги. Кравці та різники збиралися разом з учнями. Характерні річні збори відбувалися у братстві різницьких підмайстрів, вони починалися в середу перед великим постом і тривали до неділі.

Стати майстром у Львові було непросто і нелегко. Численні перешкоди були закладені у цехових статутах, а також у процесі практичної діяльності ремісника. Сувора регламентація чисельності цехових майстрів існувала тільки у двох львівських цехах: різниць- 
кому і пекарському. До 16 ст. у них було лише по 20 майстрів. Цех регламентував усі етапи виробничої діяльності ремісника - купівлю сировини, процес виробництва і збут готових товарів. Наприклад, різникам визначали кількість тварин, яких вони могли забивати на тиждень - на одну ятку 2 воли, 2 свиней, 6 баранів і 6 телят.

Ковальське ремесло теж належить до найстаріших. Про це свідчить книга записів цього цеху (Kasova knyha tsekhu kovaliv). В той час у цеху ковалів і слюсарів було 14 ковалів, 14 слюсарів, 10 мечників, 5 голкарів, 3 ножівники та 1 латнер. Кількість ковалів і слюсарів залишалася приблизно однаковою до 19 ст.

Важливу роль у забезпечені міста м'ясними продуктами відігравав львівський цех різників, який існував з 1425 року. 15-16 ст. у цеху було 20 ремісників, вони мали 40 яток, у яких продавали свої вироби. Різницьке ремесло регламентувалося цеховими статутами та численними привілеями королів. 3 розвитком міста, зростанням населення 20 цехових майстрів не могли задовольнити його потреби. Тому міська рада скасувала цехові регламентації і у 1620 р. дозволила збільшити число різників на 20 осіб. Для продажу м'яса визначалося 40 яток, також виділялися нові місця біля Краківської і Галицької брам.

Отже, цехи до початку 19 ст. були вищими начальними закладами. Для університетів ветеринарного профілю вчених ковалів, різників готували лише цехи, що давали добрі вміння і практичні навички. Підготовка лікувальників тварин у Європі, а відповідно і в Україні довгий час проводилися при цехах ковалів.

Протягом XV - першої половини XVII століття Львів був ремісничим, освітнім та культурним центром України завдяки тому, що стояв на перетині великих європейських шляхів та був відомим ринковим центром збуту, обміну та товарного виробництва у Центральній та Південній Європі. Підтвердженням цього $є$ відкриття у 1439 році релігійнопросвітницького товариства «Львівське братство». В 1460 році у Львові вже існувала друкарня Степана Дропана, яка друкувала латинською мовою біблії i підручники, а в 1572 році Іван Федорович (Иван Фёдоров) відновив у місті книгодрукування, але вже руською мовою для забезпечення бібліями та підручниками школи Львівського братства.

Вперше документально зафіксовано існування цехів у Львові в грамоті 1386 року, в якій Перемишський староста Андрій від імені Руського князя Володислава Опольського дарує місцевим шевцям такі ж права, як і львівському цеху шевців.

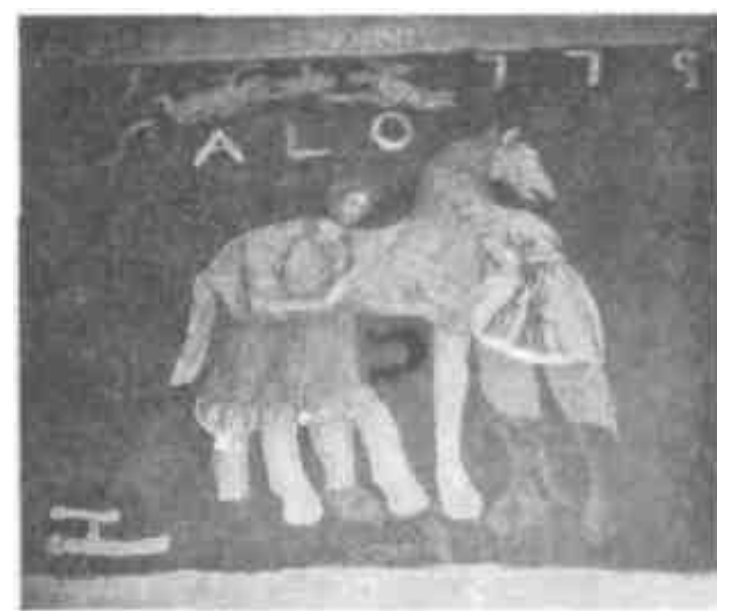

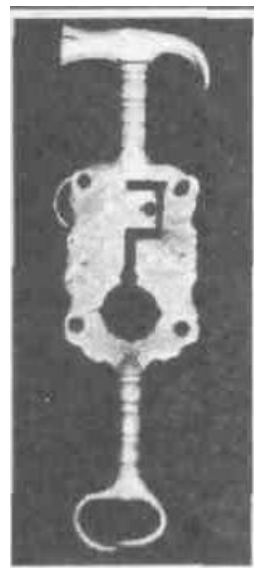

a
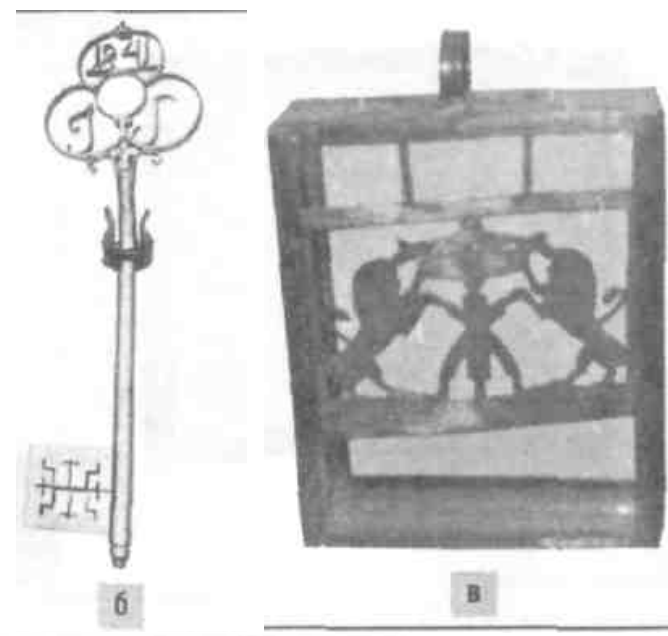

B

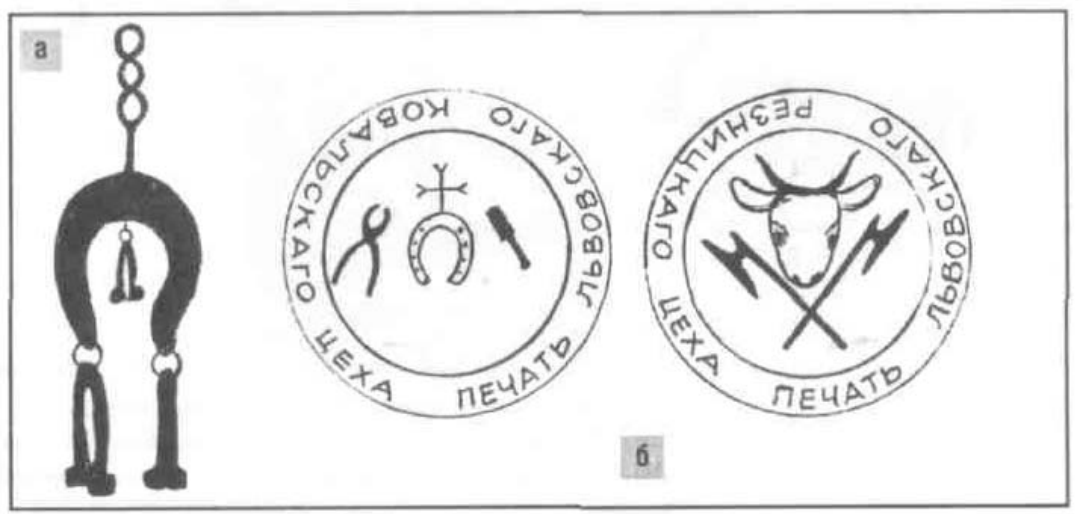

Середньовічні архівні документи XIV- першої половини XVII століття (цехові статути, книги запису поточних справ, актові книги міської влади) досить повно відображають цехову структуру Львова не тільки кількісно, а й фахово. У Львові в XIV столітті

було чотири, а в 1425 році вже діяло 10 цехів: ковалів, сідлярів, різників, шевців, крамарів, пекарів, кушнірів, лимарів, гарбарів та пивоварів. У 1579 році було вже 20 цехів, а в першій половині XVII століття кількість 
цехів у Львові досягла 30, в які об’єднались понад 500 майстрів 133 спеціальностей.

Збереглося зображення печатки Львівського цеху 1425 року, якою ремісники міста стверджували свою присягу королеві Владиславу II. Центральне місце в композиції печатки займають символи ковальського ремесла: кліщі і підкова.
Кожний ковальський цех мав цехову скриньку, в якій зберігалися привілейні грамоти, статути, цехові книжки чи грошові внески. У Львівському державному історичному архіві зберігаються два найдавніші статути ковальського цеху 1529 і 1558 рр.

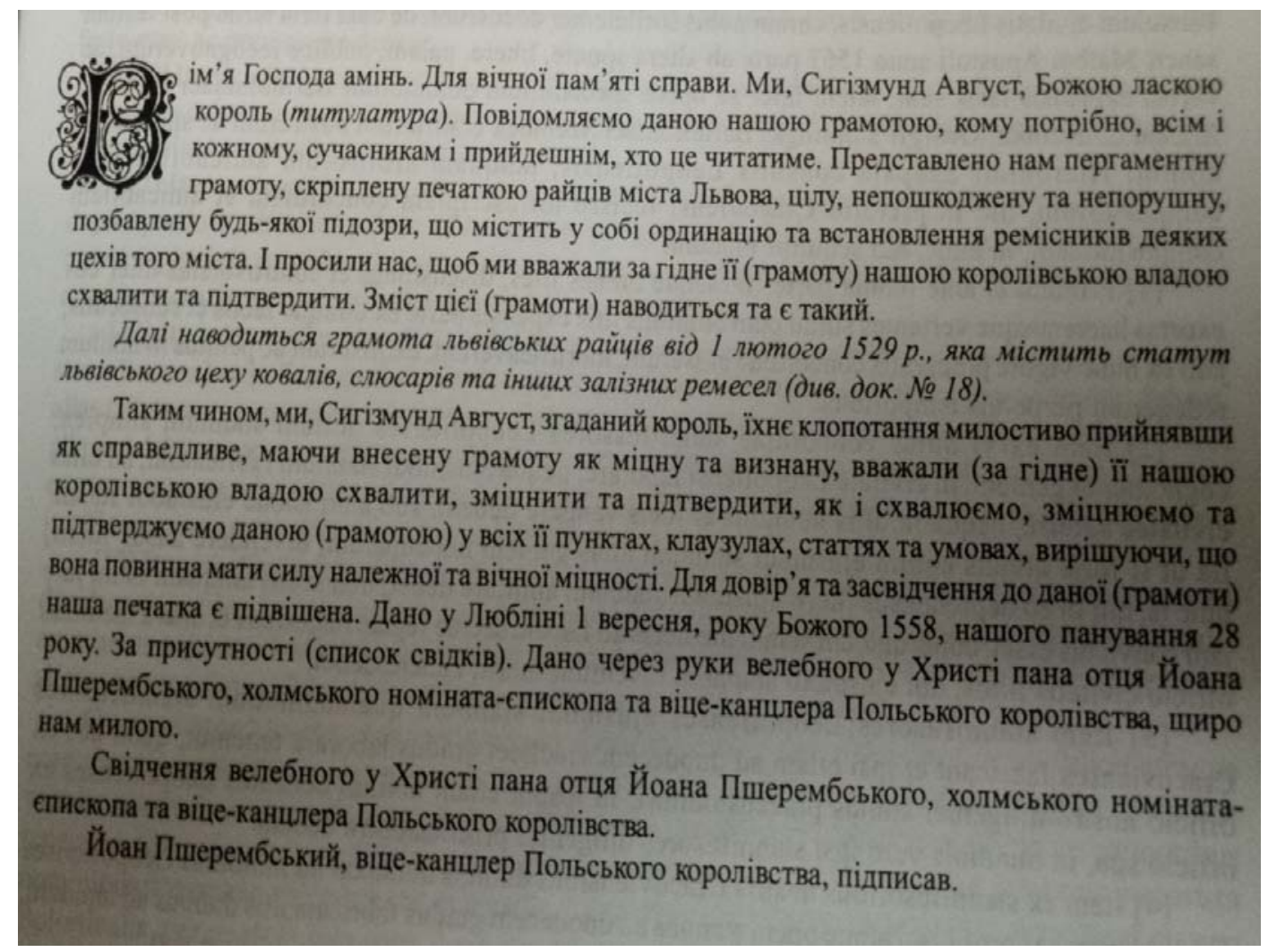

У зв'язку з розвитком конярства і використанням коней як основної верхової, тяглової та робочої сили на селі, а також в армії під час військових дій 3'явилася потреба у кінських майстрах, ковалях. Ковалі займались не лише підковуванням коней, а з часом і лікуванням та кастрацією. У подальшому ковалі-коновали займалися лікуванням не тільки коней, а й інших тварин. Особливо в боротьбі 3 пошесними захворюваннями тварин вони збагачували досвід лікувальної практики, який передавали наступним поколінням.

Проте все це були навчальні заклади, в яких готували невелику кількість фахівців лікувальної справи, а більшу частину населення i тварин обслуговували знахарі, кровопускачі, ковалі, коновали. Таким чином, ветеринарна освіта у Львові має глибоке коріння, яке необхідно відроджувати та пам'ятати і водночас зберігати національні традиції підготовки лікарів ветеринарної медицини при входженні до європейської спільноти.

\section{Висновки}

1. Першими фахівцями лікувальної справи тварин у давні часи в Галичині були пастухи, скотарі, вівчаpi, коновали, ковалі.
2. Зародження і розвиток цехової структури було наслідком піднесення економічно-торгівельних та культурно-освітніх зв'язків у середньовічному Львові, що дало початок лікувальній справі тварин, а в подальшому - відкриттю шкіл і зародженню ветеринарної освіти в Галичині.

Перспективи подальших досліджень. Планується дослідити організацію ветеринарно-санітарного і митного контролю та їх роль в розвитку лікувальної справи і тваринництва в Галичині.

\section{Бібліографічні посилання}

Aranchii, S.V. (1998). Istoriia veterynarnoi medytsyny Poltavshchyny. Poltava: Poltavskyi literator (in Ukrainian).

Bogojavlenskij, N.A. (1980). Drevnerusskoe vrachevanie v H1-HUIIst. M. (in Russian).

Verbytskyi, P.I., Dostoievskyi, P.P., Rudyk, S.K. (2002). Istoriia veterynarnoi medytsyny Ukrainy. K. Vetinform (in Ukrainian).

Verkhratskyi, S.A., Zabludovskyi, P.Iu. (1991). Istoriia medytsyny. Kyiv (in Ukrainian).

Sadvari, Yu.Iu., Bakhtyn, V.F., Dudash, A.V. (2000). Veterynarna medytsyna Zakarpattia na mezhi tysiacholit. Uzhhorod: Patent (in Ukrainian). 
Kis, Ya.P. (1968). Promyslovist Lvova u period feodalizmu. Lviv (in Ukrainian).

Kurtiak, B.M., Tkachuk, P.S. (2001). Narys istorii veterynarnoi medytsyny Lvivshchyny. Lviv: Triada plius (in Ukrainian).

Rudyk, S.K., Bisiuk, I.Iu. (2000). Istoriia veterynarnoi medytsyny Kyivshchyny. K. Ahrosvit (in Ukrainian).

Sytarchuk, V. (2002). Istoriia veterynarnoi medytsyny Rivnenshchyny. Rivne (in Ukrainian).

Tsentralnyi derzhavnyi istorychnyi arkhiv Ukrainy $\mathrm{u}$ m. Lvovi (TsDIA), Fond 52, Opys 2, Sprava 8 (in Ukrainian).

Vytiahy z Lvivskykh zemskykh i miskykh aktiv u spravakh mista za 1411-1786 rr. TsDIA m. Lvova. F. 52, O. 2, 644 (in Ukrainian).
Knyha zapysiv protokoliv vyzvolennia tsekhu kovaliv. TsDIA m. Lvova. F. 52, O. 2, S. 989-995 (in Ukrainian).

Kodeks pryvileiv i prav $\mathrm{m}$. Lvova za 1356-1685 rr. Ukladach Antonii Alembek. TsDIA m. Lvova. F. 52, O. 2, 1153 (in Ukrainian).

Kasova knyha tsekhu kovaliv. TsDIA m. Lvova. F. 52, O. 2, 996-999 (in Ukrainian).

Received 2.10.2017 Received in revised form 31.10.2017 Accepted 6.11.2017 